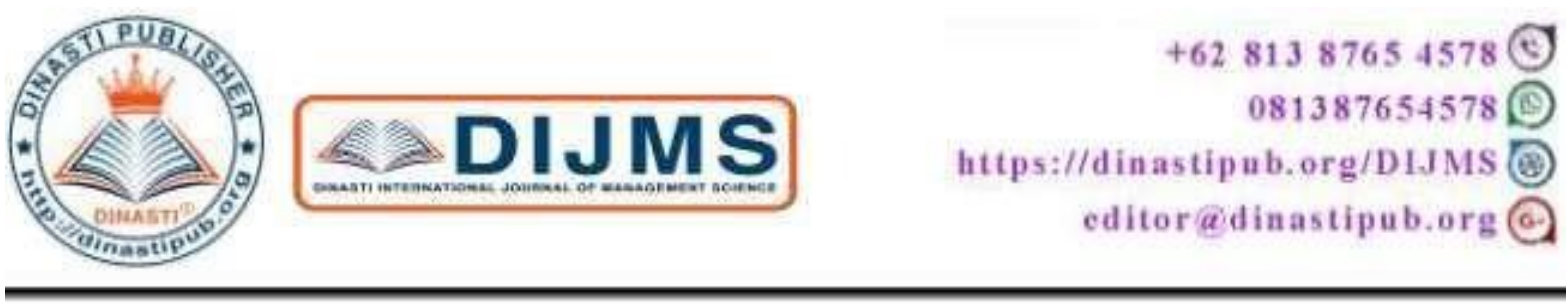

\title{
BUILDING TEACHER DISCIPLINE THROUGH ANALYSIS OF ORGANIZATIONAL CULTURE AND MOTIVATION (Case Study at SMK Mitra Karya Karawang).
}

Rajab Muh ${ }^{1}$, Munawar N.A. ${ }^{2}$

${ }^{1,2)}$ University of Mercu Buana (UMB), Jakarta, Indonesia

\begin{tabular}{|l|l|}
\hline ARTICLE INFORMATION & $\begin{array}{l}\text { Abstract: This study aims to analyze the influence of } \\
\text { Received: 10 March 2020 } \\
\text { organizational culture, and work motivation towards } \\
\text { Revised: 22 March 2020 } \\
\text { Issued: 27 March 2020 } \\
\text { primary data were derived from questionnaires and the } \\
\text { secondary data were from school statistics. The } \\
\text { population of the research was all college teachers in } \\
\text { SMK Mitra Karya Karawang. The research method is: } \\
\text { quantitative research that uses the survey method in } \\
\text { question is to explain the causal influence or correlation } \\
\text { which is commonly referred to as path analysis with the } \\
\text { data analysis technique used in this research is SEM } \\
\text { (structural equation modeling) lisrel 8.8. The } \\
\text { muhammad.rajab@gmail.com } \\
\text { respondents were 150 teachers of Mitra Karya Karawang } \\
\text { Vocational School with a minimum service period of } 1 \\
\text { year. The results show that organizational culture, anda } \\
\text { work motivation together have a significant effect on } \\
\text { work discipline. Partially organizational culture and } \\
\text { work motivation have a significant positive effect on } \\
\text { work discipline. The most work motivation is a powerful } \\
\text { variable of influence on discipline work. } \\
\text { Keywords: Organizational Culture, Work Motivation, } \\
\text { Job Satisfaction, Discipline Of Teacher Work. }\end{array}$ \\
\hline
\end{tabular}

\section{INTRODUCTION}

Global competition requires the existence of Human Resources (HR) that are reliable and professional. HR has a more strategic role than other resources. This requires organizations to be more competitive. Organizations must have advantages and competitiveness, so that they can survive among other organizations. Human Resources (HR) that are reliable and professional are inseparable from the role of the education world.

Talking about education in Indonesia is inseparable from the role of teachers as educators. Teachers are the spearhead of education, not only in formal education but also in non-formal education. There is no doubt that the role of the teacher in educating the next 
generation of the nation is very important, because its role is very vital in directing the young generation of the nation to develop this country.

Teachers are required to always give the best performance in carrying out their profession. Not only in teaching students, but also to their superiors, a teacher must be able to take responsibility for his actions and must always maintain performance. Teacher discipline becomes one of the study materials that will not be finished to be discussed, this is because there are so many factors that can affect the discipline of a teacher both from within and from outside the individual teacher himself.

The problem regarding work discipline is the lack of compliance with the working hours rules made by the organization. Discipline is a social aspect that needs to be understood, grows from within and must be done to implement the rules. Work discipline is an important element for organizations to achieve organizational goals. Teacher's work discipline is closely related to absenteeism because a teacher is said to be undisciplined, one of which is if the teacher has a high level of absenteeism. Likewise with coming and going home from work the teacher does not comply with the applicable rules and regulations.

From the description above, the researcher is interested in conducting a study of the discipline of teachers, organizational culture and motivation of teachers at work. To find out what phenomena occur with the discipline of the teachers. In analyzing this phenomenon, the researchers conducted a preliminary study to find out what factors caused the discipline of the teachers to decline, as stated by the headmaster of the Mitra Karya Vocational School, Karawang.

Still according to the Principal of SMK Mitra Karya Karawang that teacher attendance at his school never reached $100 \%$ even in fact the presence of teachers at school in the period 2014 to 2017, attendance of teachers in the classroom has increased and decreased this will result in disruption of teaching and learning activities in schools Karawang Mitra Vocational School. Seeing the phenomenon that occurs, the researchers conducted a pre-survey of 30 teachers who teach at SMK Mitra Karya Karawang with the aim to find out what factors are causing the discipline of the teachers at SMK Mitra Karya Karawang has decreased. The questionnaire that examined was distributed to 30 SMK Mitra Karya Kerawang teachers as follows; What factors can increase the discipline of teachers in carrying out their duties. Following are the attendance data and pre-survey results data:
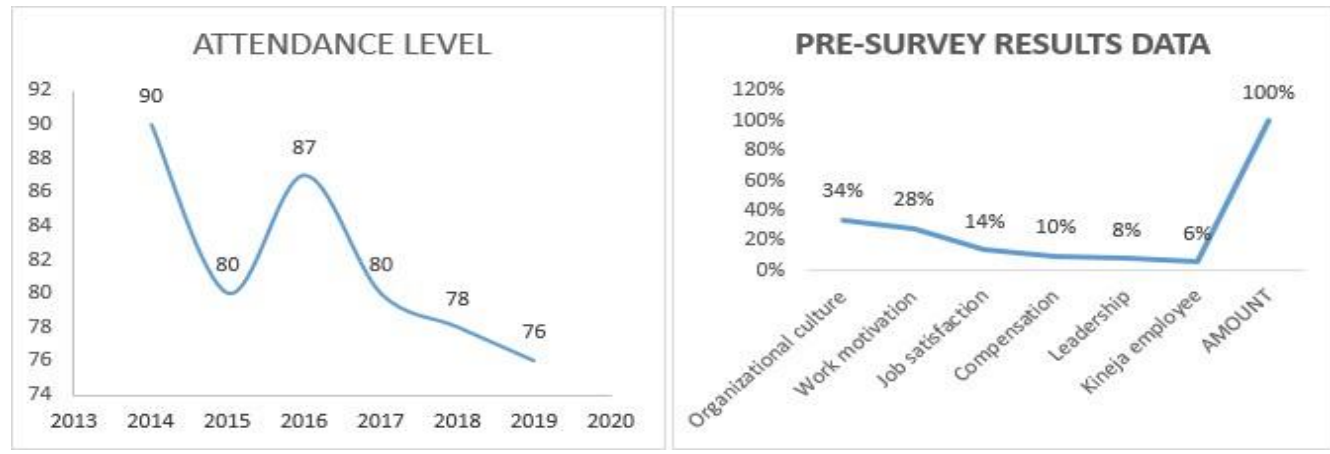

Source: Data processed by researchers(2020)

Figure 1. Data level attendance and results of pre-survey 
Based on Figure 1 we can see the level of attendance of Mitra Karya Karawang Vocational School teachers continues to experience a decrease in attendance discipline from 2014 to 2019 the attendance of teachers has decreased significantly, especially in 2019 the attendance of Mitra Karya Karawang Vocational School teachers reaches 76\%, is warming for the foundation where the presence of a teacher is one of the quality components of an educational institution.

As for the results of the pre-survey data show that the factors that most determine the discipline of teachers are organizational culture factors, work motivation, job satisfaction, compensation, leadership, and performance. Factors that are quite significant in influencing discipline according to pre-survey data are organizational culture and work motivation while other factors researchers consider less so significant. Both factors such as organizational culture and work motivation are quite interesting for researchers to analyze. Therefore, researchers will focus on analyzing these two factors. This research is focused on how to build discipline of teachers through organizational culture factors and work motivation both directly and indirectly. This research was conducted in the Karawang district of West Java province.

Based on the background and problems above, the objectives to be achieved from this study are:

1. Analyzing the influence of organizational culture on teacher discipline

2. Analyzing the influence of organizational culture on teacher performance

3. Analyzing the effect of organizational culture on work motivation of teachers

\section{LITERATURE REVIEW}

\section{Definition of Discipline}

Discipline is an attitude of employees such as respect, a sense of responsibility towards the rules and work rules of the company. Discipline is a process in which the conditions of employees comply with all the rules both a set of rules together with the rules set by the company based on labor laws. Work discipline attitude possessed by employees is very important for a company in order to realize company goals. Without good employee discipline, it is difficult for a company to achieve optimal results. Good discipline reflects the amount of responsibility someone has for the tasks assigned to him. This encourages work enthusiasm, work morale and the realization of company goals. Disiplin reflected in the attitude of the employees to comply with and obey the rules or regulations of the company, and an awareness of the employees in its willingness to comply with all company rules and social norms prevailing mental attitude is also reflected in the actions or behavior of individuals, groups or communities in the form of obedience (obedience) to the rules or regulations set by the government or ethical norms and rules that apply in society for certain purposes.

Management experts define discipline as "an attitude of willingness and willingness to obey and obey the norms of regulations that apply around it(Singodimedjo in Edy Sutrisno, 2016: 86). Discipline is someone's awareness and willingness to obey all company regulations and social norms that apply (Malayu SP hasibuan, 2012: 193). And discipline can also be defined as a person's behavior in accordance with regulations, existing work 
procedures or discipline is the attitude, behavior, and actions in accordance with the regulations of the organization both written and unwritten (Edy Sutrisno, 2016: 89)

From some of the opinions above then the researcher can synthesize that discipline is the attitude or willingness of a person or group to obey and obey the rules that apply in an organization whether the rules are set together in writing or not in writing or the rules set by the government through the law.

\section{Definition of Work Motivation}

A reason that encourages an employee to work in a company is motivation. The policy of a company or an organization that accommodates employee work motivation will have a positive impact on employee work results. There are various forms of motivation that encourage an employee in a company and organization including an employee being motivated to work better or work in a company because he is motivated by getting a monthly salary, achieving career goals, working, seeking experience, and worship.

According to experts in human resource management work motivation can be defined as "psychological processes that arouse and direct goal directed behavior", namely motivation is a psychological process that awakens and directs behavior that influences goals ( Kinicki and Kreitner, 2008: 147). Work motivation can also be interpreted as "to be motivated means to be moved to do something. A person who feels no impetus or inspiration to act it thus characterized as unmotivated, whereas someone who is energized or activated towards an end is considered motivated (Koh, 2015: 13). It was explained that motivation as something that gives encouragement to individuals to do something desired work in accordance with the inspiration or desire of the individual. Individuals who have motivation such as getting energy to do the work while for individuals who do not do something work is considered to have no motivation.

Then according to Greenberg (2010: 76) motivation is "the strength of an individual's desire to excel at various tasks - to succeed and to do better than others" ie the strength of an individual's desire to be better at various tasks - to be successful and to be better from the other. People who have high achievement motivation, according to Greenberg, will want to perform with moderate difficulties, while those who have low achievement motivation will want to work with performance with easier or more difficult difficulties. Motivation is something that is able to influence the skills developed by individuals, the work and career pursued by individuals, and the way individuals allocate their resources (for example, attention, effort, time, and human and social capital) to influence the direction, intensity, and persistence of activities during work (Kanfer, 2017: 341).

Based on the description above, it can be concluded that motivation comes from 2 sources, namely the source of desire arising from within human beings (internal sources), and sources originating from outside human beings or the environment (external). With motivation, it can change individuals to do something to get something that is wanted and expected. Motivation can trigger every individual in the organization / company to try and continue to race in improving their ability to achieve a desired goal. By continuing to improve the ability at work, individuals are directly involved in the scope of the organization / company. Of course, this involvement is due to individual productivity factors as employees in showing excellent service performance. 


\section{Definition of Organizational Culture}

In general, organizational culture is a set of principle systems that are jointly recognized and applied by all elements of the organization where this series is a differentiator between one organization to another. Organizational culture can be defined as a way for organizations to interact with an integrated environment of behavior, assumptions, stories, ideas, myths and thoughts that emphasize the meaning of working in organizations. The assumptions then develop in a group to become a reference for behavior in the organization. This habit will be passed on to future generations as a perspective, the basis for acting in organizations.

According to experts, organizational culture can be defined as a basic mindset taught to new personnel as a way to feel, think and act correctly from day-to-day (Luthans, 2011: 137). Organizational culture refers to the system of shared meanings shared by members that distinguishes the organization from other organizations. This shared coercive system, if observed more closely, is a set of main characteristics valued by the organization (Robbins and Judge in Wibowo, 2010: 256). According to Suwarto and Koesharto (2010) In general, a company or organization consists of a number of people with diverse backgrounds, personalities, emotions and egos. The results of the addition and interaction of various people form organizational culture. Simply put, organizational culture can be defined as the unity of people who have the same goals, beliefs and values.

Organizational culture is the values, beliefs and basic principles that are the foundation for management systems and practices as well as behaviors that enhance and strengthen these principles (Riani, 2011: 7). Organizational culture is a framework that serves as a guide for daily behavior in making decisions for employees and directing their actions to achieve organizational goals (Rivai and Mulyadi, 2012: 374).

Based on some definitions above, a conclusion can be drawn that organizational culture is philosophy, ideology, values, assumptions, beliefs, hopes, attitudes and norms that are shared which are binding and are a form of how people in organizations behave and do things what can be done to distinguish the organization from other organizations.

\section{Conceptual Frameworks}

1. The influence of organizational culture on work discipline

Analysis of the influence of organizational culture on work discipline has been widely studied by previous researchers including by Personal, Muhammad. Herlena, Benny (2016) with the results of the study showed a significant relationship between organizational culture and work discipline among employees in the production directorate of PT Krakatau Steel (Persero) Tbk Cilegon. Research conducted by Puspita, G. (2018), with the results of the study showed the average response of employees to strong employee work culture. Employee responses to the average work climate are good. Employee responses to work discipline are high on average. Simultaneously work culture and work climate have positive and significant effect on work discipline. Partially shows that work culture and work climate have a positive and significant effect on work discipline. The results of research conducted by D Damayanti, M Fakhri (2014) with the results of his analysis stated that there is a significant influence of organizational culture on the work discipline of employees of PT Angkasa Pura II (Persero) Main Branch Office (KCU) Soekarno-Hatta International Airport Personnel Unit \& General Affairs. 
Based on the results of previous studies described above, the influence of organizational culture on employee work discipline is a significant influence. From the results of the analysis note that when the organizational culture supports the work environment it will encourage employee work discipline.

2. The influence of organizational culture on work motivation

Analysis of the influence of organizational culture on work motivation has been much confirmed from the results of previous studies including research conducted by Sutoro, S. (2020) with the results of the analysis that organizational culture has a positive and significant influence on employee motivation in BPSDM Province. Research conducted by Masykur, R..et.al (2019) with the results of the analysis states that organizational culture significantly influences the work motivation of teachers. Same with the results conducted by researchers Sutoro (2020), Masykur, R.ET.al (2019) research conducted by Purba, MA (2017). States that the influence of organizational culture on employee work motivation based on the results of data analysis has a positive effect on motivation employee work.

It is clear that the three previous researchers with research in various fields and different objects produced the same research results that there is an influence of organizational culture on work motivation.

3. The influence of work motivation on work discipline

There are several results of research that support the theory of the influence of work motivation on work discipline including the results of research conducted by Saputra, T. (2019). The results of the study based on regression analysis found there is an influence of work motivation on employee work discipline positive correlation coefficient means it has a direct relationship. The better the motivation possessed by an employee, the higher the employee's work discipline, Conversely, if the employee's work motivation is low, the work discipline will also be low, therefore company leaders, especially hotels continue to provide motivation to employees to be able to improve work discipline. Saputra, T. (2016). The results of work motivation variables have a directional relationship meaning that there is an influence of work motivation on work discipline. The better motivation possessed by an employee will be reflected in the discipline of the employee. Good work results are certainly based on good motivation too. Conversely, if the employee's work motivation is not well developed, it will lead to careless work results and may threaten the achievement of organizational goals. Research conducted by Sanjaya, J. (2020), one of which analyzed the effect of work motivation on work discipline. The results of this study indicate that motivation has a positive and significant effect on the work discipline of BMT Pahlawan and Istiqomah Tulungagung employees. Simultaneously motivation has a positive and significant effect on the work discipline of BMT Pahlawan and Istiqomah Tulungagung employees.

From the results of the analysis of previous researchers it can be synthesized that there is an influence of employee work motivation on employee work discipline. The higher the motivation of employees at work, the better the discipline of employee work, of course, the better the performance of employees at the company.

Based on the explanation above about the flow of thought between research variables by referring to the results of previous research and expert opinion, it can be illustrated through the framework of the research model as follows: 


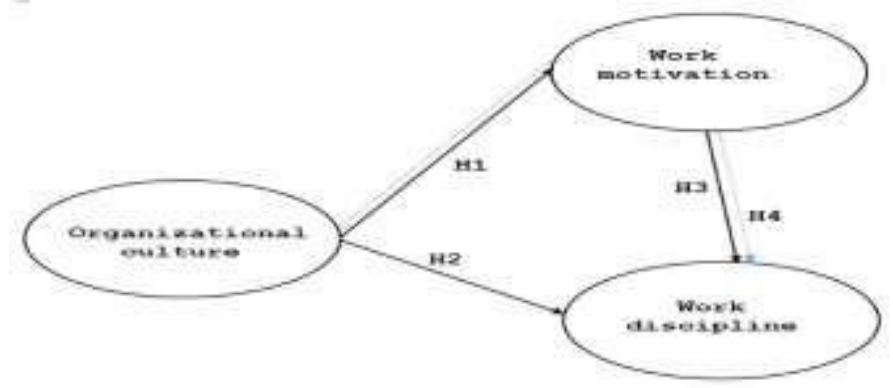

Source: Data processed by researchers(2020)

Figure 2. Concetual Framework

\section{Research Hypothesis}

Based on the research objectives, the research hypotheses are:

1) H1: Work culture has a positive and significant effect on work discipline .

2) H2: Work culture has a positive and significant effect on work motivation

3) H3: Work motivation has a positive and significant effect on work motivation

4) H4: Work culture has a positive and significant effect through work motivation on work discipline

\section{RESEARCH METHODS}

This research method is a form of quantitative research which uses survey methods with data analysis techniques using SEM (structural equation modeling) .- Lisrel 8.8. The intended survey research is to explain causal relationships or correlations commonly referred to as path analysis. The research location is Mitra Karya Karawang Vocational School conducted in the period December 2018 - June 2019.

The population in this study was Mitra Karya Karawang Vocational School with a minimum of 1 year work period. Analysis tools in the form of questionnaires were distributed to Mitra Karya Karawang Vocational School teachers. The sample used in this study was 150 respondents. Sampling is done by purposive sampling of the population that has been determined, meaning that the sample is determined by considering the research objectives and based on predetermined criteria.

\section{FINDINGS AND DISCUSSION}

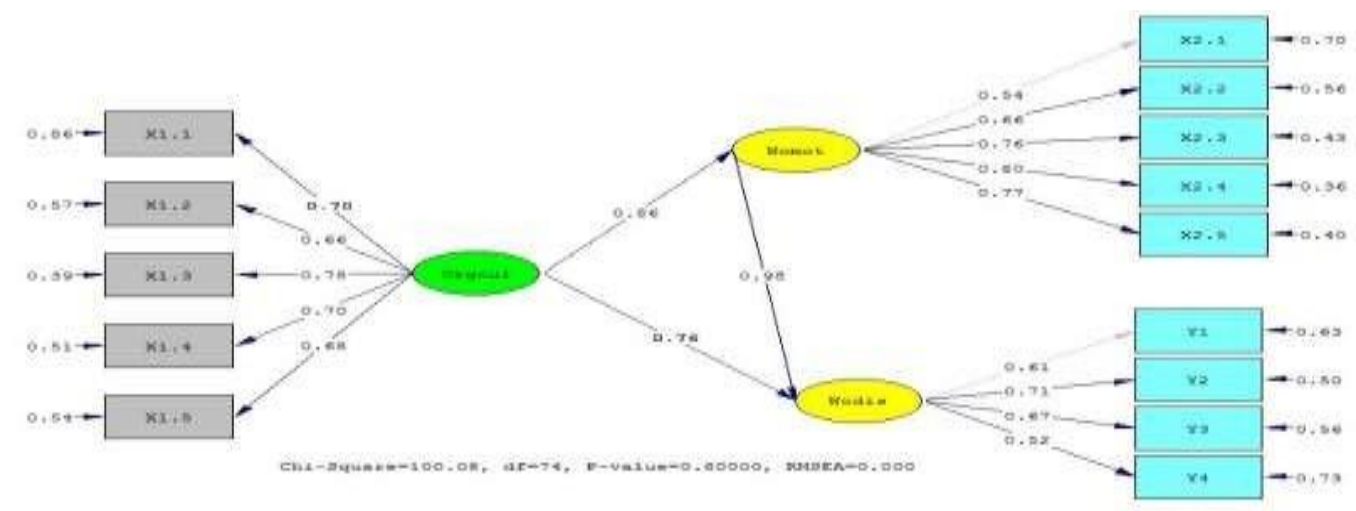

Source: Processed by researchers (2020)

Figure 3. Full model SEM 
Judging from the results of the SEM print out in Figure 1.3, the full SEM model, it can be analyzed that all variables both organizational culture variables (X1), work motivation (X2) and work discipline (Y) show loading factors that support have a factor loading value> 0.5 which means that the next analysis model can be carried out. Organizational culture supported by 5 factors has a loading factor value> 0.5 then in the first stage CFA does not experience elimination or treatment of each supporting factor of organizational culture. Likewise in work motivation with 5 manifest variable factors, all manifest variables of work motivation have a loading factor $>0.5$. Endogenous work discipline variables with 4 manifest variables have factor loading values $>0.5$, so that all manifest variables both exogenous and endogenous in this model no longer require special treatment or improvement of the model.

\section{Confirmatory Factor Analysis}

\section{Test the Validity and Reliability of CFA 1st Order Reliability}

Based on the results of the SEM Lisrel print out, we will test the validity and reliability of CFA 1 st order. As the results can be seen in table 1.

\section{Table.1}

Test Validity and Reliability of the 1st Order CFA Measurement Model

\begin{tabular}{|c|c|c|c|c|c|c|c|c|}
\hline $\begin{array}{c}\text { Laten } \\
\text { Variabel }\end{array}$ & $\begin{array}{l}\text { Variabel } \\
\text { Manifes }\end{array}$ & $\begin{array}{c}\text { Factor } \\
\text { Loading }\end{array}$ & $\begin{array}{l}\text { Critical } \\
\text { Faktor } \\
\text { Loading }\end{array}$ & Decision & CR & AVE & $\begin{array}{l}\text { Critical } \\
\text { Value }\end{array}$ & Decision \\
\hline \multirow{5}{*}{$\begin{array}{l}\text { Organizational } \\
\text { culture(X1) }\end{array}$} & $\mathrm{X} 1.1$ & 0,70 & 0,5 & valid & \multirow{5}{*}{0,8} & \multirow{5}{*}{0,5} & \multirow{5}{*}{$0.5-0.70$} & \multirow{5}{*}{ Reliable } \\
\hline & X1.2 & 0,66 & 0,5 & Valid & & & & \\
\hline & X1.3 & 0,78 & 0,5 & Valid & & & & \\
\hline & X1.4 & 0,70 & 0,5 & Valid & & & & \\
\hline & $\mathrm{X} 1.5$ & 0,68 & 0,5 & Valid & & & & \\
\hline \multirow{5}{*}{$\begin{array}{c}\text { Work } \\
\text { Motivation(X2) }\end{array}$} & $\mathrm{X} 2.1$ & 0,54 & 0,5 & Valid & \multirow{5}{*}{0,8} & \multirow{5}{*}{0,5} & \multirow{5}{*}{$0,5-0,70$} & \multirow{5}{*}{ Reliable } \\
\hline & $\mathrm{X} 2.2$ & 0,66 & 0,5 & Valid & & & & \\
\hline & $\mathrm{X} 2.3$ & 0,76 & 0,5 & Valid & & & & \\
\hline & X2.4 & 0,80 & 0,5 & Valid & & & & \\
\hline & $\mathrm{X} 2.5$ & 0,77 & 0,5 & Valid & & & & \\
\hline \multirow{4}{*}{$\begin{array}{c}\text { Work } \\
\text { discipline }(\mathrm{Y})\end{array}$} & Y1 & 0,61 & 0,5 & Valid & \multirow{4}{*}{0,7} & \multirow{4}{*}{0.5} & \multirow{4}{*}{$0,5-0,70$} & \multirow{4}{*}{ Reliable } \\
\hline & $\mathrm{Y} 2$ & 0,71 & 0,5 & Valid & & & & \\
\hline & Y3 & 0,67 & 0,5 & Valid & & & & \\
\hline & Y4 & 0,52 & 0,5 & Valid & & & & \\
\hline
\end{tabular}

Source: Processed by researchers(2020)

In table 1 all the instruments used in this model both organizational culture variables, motivation and work discipline have a loading factor> 0.5 and Construct Reliability (CR) value $>0.5$ or $>0.70$. While the value of $A V E \geq 0.5$, thus the instruments in this model can be declared Valid and Reliable.

The following are the Fit Model Indicators which are illustrated in the table below:

Table 2.

Indikator Fit Model

\begin{tabular}{cl}
\hline Item & \multicolumn{1}{c}{ Indikator } \\
\hline & Organizational culture(ORGCUL) \\
\hline $\mathrm{X} 1.1$ & Innovative (X1.1) \\
$\mathrm{X} 1.2$ & People Orientation (X1.2) \\
$\mathrm{X} 1.3$ & Result Orientation (X1.3)
\end{tabular}




\begin{tabular}{lc} 
X1.4 & Team Orientation (X1.4) \\
X1.5 & Aggressiveness (X1.5 \\
\hline \multicolumn{3}{c}{ Work motivation(WOMOT) } \\
\hline X2.1 Need for Achievement (X2.1) \\
X2.2 & Responsibility Needs $\quad(\mathrm{X} 2.2)$ \\
X2.3 & Strength Requirement $\quad(X 2.3)$ \\
X2.4 Award Needs (X2.4) \\
X2.5 Friendship Needs (X2.5 \\
\hline \multicolumn{2}{c}{ Work Discipline(WODIS) } \\
\hline Y1 & Goal Ability (Y1) \\
Y2 & Work Standards Compliance (Y2) \\
Y3 & Compliance with Work Regulations (Y3) \\
Y4 & Work Ethics (Y4) \\
\hline
\end{tabular}

Source: Processed by researchers(2020)

\section{Second Order CFA (2ndCFA)}

\section{a. Model Fit Test}

The next test is testing the model compatibility or goodness of fit. This test is conducted to determine whether the model used is fit or not. If the statistical analysis shows fit then overall that the sample covariance matrix is the same as the estimated covariance matrix. But if the statistical analysis of this model is not fit then overall the sample covariance is not the same as the estimated covariance matrix. Therefore, if this happens, we must modify the model based on the lisrel modification index, ie by correlating or freeing the error variance between manifest variables.

Here are the results of the SEM printed out of the lisrel shown in table 1.1 below:

\section{Table 4}

\section{Goodness of Fit Statistics}

\begin{tabular}{|c|c|c|c|}
\hline $\begin{array}{c}\text { GOF } \\
\text { MEASUREMENT }\end{array}$ & $\begin{array}{l}\text { ESTIMATION } \\
\text { RESULTS }\end{array}$ & CRITERIA & CONCLUSION \\
\hline \multirow{2}{*}{ Statistcs $\lambda^{2}$} & $\mathrm{df}=4$ & $0 \leq \lambda^{2} \leq 2 \mathrm{df}$ & \multirow{2}{*}{ Fit } \\
\hline & $\lambda^{2}=100.8$ & $2 \mathrm{df}<\lambda^{2} \leq 3 \mathrm{df}$ & \\
\hline \multirow{2}{*}{ p-Value } & \multirow{2}{*}{0.8} & $0.05 \leq \mathrm{p} \leq 1.00$ & \multirow{2}{*}{ Fit } \\
\hline & & $0.01<\mathrm{p} \leq 0.05$ & \\
\hline $\mathrm{NCP}$ & 0.25 & Harus lebih kecil & Fit \\
\hline \multirow{2}{*}{ RMSEA } & \multirow{2}{*}{0.000} & RMSEA $\leq 0.08$ & \multirow{2}{*}{ Fit } \\
\hline & & RMSEA $\leq 0.05$ & \\
\hline ECVI & 8.0 & $\begin{array}{l}\text { Harus lebih kecil dari } \\
\text { Saturated ECVI(8.18) }\end{array}$ & Fit \\
\hline Model AIC & 920.30 & $\begin{array}{l}\text { Harus lebih kecil dari } \\
\text { Saturated AIC(930.18) }\end{array}$ & Fit \\
\hline Model CAIC & 1130 & $\begin{array}{l}\text { Harus lebih kecil dari } \\
\text { Saturated CAIC(1140) }\end{array}$ & Fit \\
\hline \multirow{2}{*}{ NFI } & \multirow{2}{*}{0.98} & $\mathrm{NFI}>0.90$ & \multirow{2}{*}{ Fit } \\
\hline & & $0.80<\mathrm{NFI}<0.90$ & \\
\hline NNFI/TLI & 0.94 & $\begin{array}{c}0.80<\mathrm{TLI}<0.90 \text { atau } \\
\text { NNFI }>0.90\end{array}$ & Fit \\
\hline
\end{tabular}




\begin{tabular}{l|c|c|c}
\hline PNFI & 0.29 & PNFI $<0.5$ & fIt \\
\hline \multirow{2}{*}{ CFI } & \multirow{2}{*}{0.99} & CFI $>0.97$ & \multirow{2}{*}{ Fit } \\
\cline { 2 - 3 } & & $0.90<$ CFI $<0.97$ & Fit \\
\hline IFI & 0.98 & IFI $>0.90$ & Fit \\
\hline RFI & 0.95 & RFI $>0.90$ & Fit \\
\hline CN & 600 & CN $>200$ & Fit \\
\hline SRMR & 0.045 & SRMR $\leq 0.05$ & Fit \\
\hline GFI & 0.93 & GFI $>0.90$ & Fit \\
\hline AGFI & 0.96 & AGFI $>0.89$ & Fit \\
\hline PGFI & 0.6 & PGFI $>0.5$ & .
\end{tabular}

Source: Processed by researchers(2020)

Based on table 1.2, goodness of fit can be taken an analysis that all components of GOF indicate this research model has met the criteria for goodness of fit index. Therefore, modification of the model is not needed in order to find a fit model in accordance with the criteria for goodness of fit. Because overall GOF estimation results are categorized as fit, it can be concluded that the sample covariance matrix is not much different from the estimation covariance matrix.

\section{b. Hypothesis Testing}

There are two analytical tools that researchers will use in testing this hypothesis, the first is that the researcher uses the results of the SEM lisrel printout, the structural equation of the SEM model of the research contained in Figure 4 and and the second is the T-Value diagram found in Figure 5 . Here is a picture of the structure model of the equation and TValue diagram. In this test the researcher will explain the significance of the influence between variants and the direct effect and the indirect effect between variables.

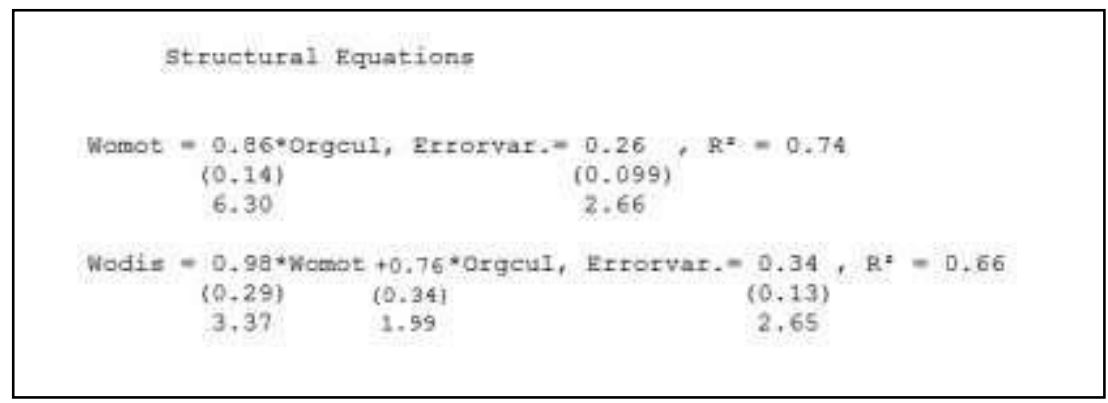

Source: Processed by researchers(2020)

Picture 4. Persamaan Struktural

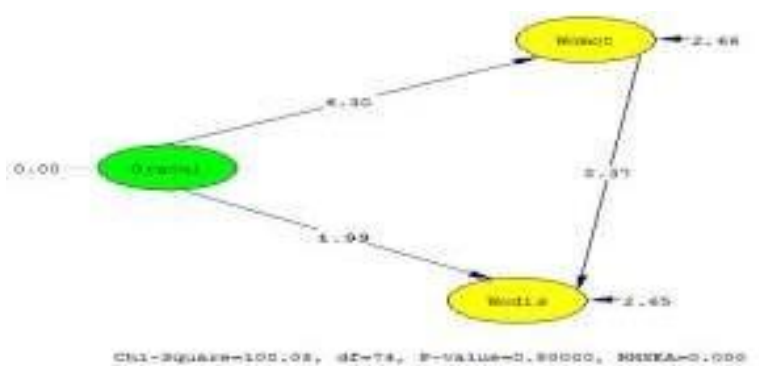

Source: Processed by researchers(2020)

Picture 5. T-Value 


\section{1) First Hypothesis}

There is a significant influence of organizational culture variables (ORGCUL) on work discipline variables (WODIS)

The coefficient of direct influence of organizational culture (ORGCUL) on work discipline (WODIS) is 0.76 , while the error value (se pk) is 0.14 . T value of 6.30 or T value generated full path diagram output> of critical value of 1.96, it can be concluded that the coefficient of direct influence of organizational culture (ORGCUL) on work motivation (WOMOT) is significant, this effect has a coefficient of determination $\mathrm{R}^{2}$ of 0.66 or about $66 \%$ of organizational culture influences work discipline. Thus, the first hypothesis stating the existence of a positive and significant influence of organizational culture (ORGCUL) on work discipline variables (WODIS) can be accepted. These results confirm the results of research conducted by Herlena, Benny (2016), Puspita, G. (2018), D Damayanti, and M Fakhri (2014). It was explained that there was a significant influence of organizational culture on work discipline.

2) Second Hypothesis

There is a significant influence of organizational culture (ORGCUL) on work motivation (WOMOT)

The coefficient of direct influence on organizational culture (ORGCUL) on work motivation (WOMOT) is 0.86 , while the error value (se pk) is 0.34 . T value of 1.99 or $\mathrm{T}$ value generated by full path diagram output> of critical value of 1.96 , it can be concluded that the coefficient of direct influence of organizational culture (ORGCUL) on work discipline (WODIS) is significant, this effect has a coefficient of determination $\mathrm{R}^{2}$ of 0.74 or about $74 \%$ of organizational culture influences work motivation (WOMOT). Thus, the second hypothesis which states that there is a positive and significant influence of organizational culture (ORGCUL) on work motivation variables (WOMOT) can be accepted. These results confirm the results of research conducted by Sutoro, S. (2020), Masykur, R..et.al (2019), Sutoro (2020), Masykur, R.ET.al (2019) and Purba, MA (2017). It was explained that there was a significant influence of organizational culture on work motivation (WOMOT).

3) Third Hypothesis

There is a significant influence of work motivation (WOMOT) on work discipline (WODIS)

The coefficient of direct influence of work motivation (WOMOT) on work discipline (WODIS) is 0.98 , while the error value (at pk) is 0.29 . T value of 3.37 or $\mathrm{T}$ value generated by full path diagram output> of critical value of 1.96 , it can be concluded that the coefficient of direct influence of work motivation (WOMOT) on work discipline (WODIS) is significant, this effect has a coefficient of determination $\mathrm{R}^{2}$ of 0.66 or around $66 \%$ of work motivation (WOMOT) affects work discipline (WODIS). Thus, the third hypothesis which states the existence of a positive and significant influence of work motivation (WOMOT) on work discipline variables (WODIS)can be accepted. These results confirm the results of a study conducted by Saputra, T. (2019). Saputra, T. (2016) and Sanjaya, J. (2020). It was explained that there was a significant influence of organizational culture on work motivation (WOMOT). 
4) There is a significant influence of organizational culture (ORGCUL) on work discipline (WODIS) throughmotivation work (WOMOT)

The coefficient of direct influence of organizational culture (ORGCUL) on work discipline (WODIS) is 0.75 , while the error value (se pk) is 010 . T value of 6.71 or $\mathrm{T}$ value generated by full path diagram output> of critical value of 1.96 , it can be concluded that the coefficient of direct influence of organizational culture (ORGCUL) on work discipline (WODIS) through work motivation (WOMOT) is significant, this effect has a value $\mathrm{R}^{2}$ determination coefficient of 0.66 or about $66 \%$ of organizational culture influences work discipline through work motivation (WOMOT). Thus, the fourth hypothesis stating the existence of a positive and significant influence of organizational culture (ORGCUL) on work discipline variables (WODIS) through work motivation (WOMOT) can be accepted.

\section{Direct Influence (DCE), Indirect (ICE) and Total Influence (TCE)}

Direct and indirect influence tests are carried out to determine whether there are direct or indirect influences (DCE) of independent variables that affect the dependent variable. Based on the results of data analysis it can be seen the direct effect (DCE) of organizational culture variables (ORGCUL) on work discipline (WODIS) of 0.76 with a T-value of 3.34, the direct effect of organizational culture variables (ORGCUL) on work motivation (WOMOT) of 0.86 with $\mathrm{T}$ - value 6.30. The direct effect of work motivation (WOMOT) on work discipline (WODIS) was 0.98 with a T-Value of 3.37, so the total direct effect (DCE) was 0.64 . While the indirect effect of organizational culture (ORGCUL) on work discipline (WODIS) through work motivation (WOMOT) is 0.84 , the total direct and indirect influence (DCE + ICE) is 1.48, the results of data analysis can be concluded that overall both good direct influence between variables and the indirect effect between variables is significant.

\section{Discussion}

1. Organizational culture (ORGCUL) significantly influences work discipline (WODIS)

As we know from the results of the analysis, this study proves that organizational culture variables significantly influence work discipline. Organizational culture can encourage SMK Mitra Karya Karawang teachers to have good work responsibilities and discipline. Creating good organizational value will encourage the motivation of teachers in teaching to increase. Support from management is a powerful way to improve the discipline of teachers at work. Encouraging organizational cultural values is a pattern of assumptions that is useful for solving problems related to adaptation to the organization's external environment and integration between organizational units. Viewed from the significant results of organizational culture on the discipline of teachers, the main problem lies in the creation of a value system by the organization where the manifestation of the core values of an organization will direct organizational members to realize the goals, vision, mission and goals of the organization. This implies that the value system in an organization is the core values of the organization that are believed to be members of the organization so that it directs members of the organization to work according to company regulations and standards.

The attitude and behavior of someone who works will be in accordance with company standards and will comply with company regulations is a form of attitude and 
work discipline behavior. Work discipline is created because the culture of the organization is used as values, principles, traditions and ways of working shared by members of the organization as a guide to work. These guidelines will influence the way they act and behave and ultimately there will be demands for professionalism in work. Organizational culture consists of dominant values that are supported by the organization or philosophy that guides organizational policies towards employees. Clear and transparent company policies affect the way work is done in the workplace. This fosters teachers' trust in organizations that can motivate teachers to work based on the company's corporate values, namely competence, integrity, reliable and innovative. Good organizational culture values are values that are measured by orientation to people, orientation to results, orientation to the team and orientation to the aggressiveness of teachers in carrying out their duties and responsibilities as educators both morally and in quality of the results of the education they provide. This is as stated by experts such as Luthans, (2011: 137), Robbins and Judge in Wibowo, (2010: 256). Suwarto and Koesharto (2010), Riani, (2011: 7). Rivai and Mulyadi, (2012: 374) that organizational culture is philosophy, ideology, values, assumptions, beliefs, hopes, attitudes and norms that are shared which are binding and are a form of how people in organizations behave and do something that can be done to distinguish the organization from other organizations.

2. Organizational culture (ORGCUL) significantly influences work motivation (WOMOT)

Based on the results of the analysis, that organizational culture positively and significantly influences work motivation. This influence is positive meaning that every change in organizational culture will affect work motivation. Work motivation will be good if the organizational culture is also good as well as if the organizational culture in a company is not good it will create a degradation of the motivation of teachers. Teachers will be increasingly motivated to produce good performance if the management of Mitra Karya Karawang Vocational School considers several factors that cause the increasing motivation of teachers to obey the rules, be loyal to management, and be careful in carryingtheir outduties. The factors that need to be considered by the organization are the need for achievement, the need for responsibility, the need for strength, the need for appreciation, and the need for friendship. Organizational behavior towards these six factors will cause the growth of trust in the organization. Work motivation is an impulse of effort and desire contained in human beings to activate, provide power and direct their behavior in carrying out duties and responsibilities in the scope of work. Organizations can encourage each individual to be motivated to work harder, obey the rules and collective agreements for the achievement of the goals of the organization itself.

The lack of discipline of the teachers of Mitra Karya Karawang Vocational School is due to the non-fulfillment of factors that can encourage the motivation of teachers. There are needs, desires, and encouragement to act for the achievement of individual needs or goals one of them by working. In working consciously he will set work goals and try to fulfill them so that in turn strives to make himself useful to the organization by producing high performance. This kind of behavior will arise when the organization or management of Mitra Karya Vocational School Karawang has a system that can be used as a shared philosophy in achieving goals between individuals and organizations. The disciplinary and non-compliance characteristics of teachers towards the organization are indicators of the 
system built by the management of Mitra Karya Karawang Vocational School which is perceived as a system that cannot be trusted and cannot meet the expectations of teachers towards the organization itself. This was stated by management experts including Kinicki and Kreitner (2008: 147), Koh (2015: 13), Greenberg (2010: 76), and Kanfer (2017: 341), explained that motivation is something that gives encouragement to individuals to do something work that is desired in accordance with the inspiration or desired individual. Individuals who have motivation such as getting energy to do the work while for individuals who do not do something work is considered to have no motivation.

3. Work motivation (WOMOT) significantly influences work discipline (WODIS).

Based on the results of the analysis of the influence of work motivation on work discipline, it is found that work motivation significantly influences work discipline. As the previous discussion that one of the factors that can motivate the teachers of Mitra Karya Karawang Vocational School in carrying out their responsibilities as educators is the organizational support of the teachers. The development of good company values will inspire teachers to work better and be responsible. But conversely when the company's value is perceived poorly, teachers will lose direction and sense of responsibility for their assignments. So in this study the researchers found that very closely the relationship between motivation and work discipline. An individual who is not motivated to achieve his desires he will do the job with no sense of responsibility and of course the discipline of an individual who is not motivated will not be disciplined. Adapun people who have low achievement motivation will be willing to work with low performance anyway. In completing their tasks, someone who has low motivation will have difficulty in carrying out their duties and responsibilities, but for someone who has high work motivation, it will be easier to carry out their duties and responsibilities. Something that is able to influence the skills developed by individuals, the work and career pursued by individuals, and the way individuals allocate their resources (for example, attention, effort, time, and human and social capital) to influence the direction, intensity, and persistence of activities during work is Motivation factors (Kanfer, 2017: 341). So it is clear that the influence of motivation on the discipline of teachers is a very strong and significant influence where discipline will not be achieved if every individual in the company is not motivated. This is as the result of research conducted by Saputra, T. (2019). Saputra, T. (2016). Sanjaya, J. (2020), that motivation is a driver of work discipline or that motivation affects work discipline.

4. Organizational culture (ORGCUL) has a significant effect on work discipline (WODIS) throughmotivation work(WOMOT).

According to the results of the analysis in this study work culture has an effect on work discipline through work motivation. This means that with the improvement of the quality of work culture in the company it will be increasingly motivated by its employees to work better by referring to compliance with collective agreements and company regulations with applicable laws. Work discipline will increase if employees feel motivated to achieve a goal they want to achieve. 


\section{CONCLUSION AND SUGESTION}

\section{Conclusions}

The results of this study reinforce the theory that:

1. There is a positive and significant influence of organizational culture on work discipline where these results are confirmed with the theory and results of previous studies.

2. There is a significant influence of organizational culture on work motivation on SMK Mitra Karya Karawang teachers

3. There is a significant influence of work motivation on the work discipline of SMK Mitra Karya Karawang teachers

4. There is a significant influence of work culture on work discipline through motivation work for Mitra Karya Karawang Vocational School teachers

\section{Suggestion}

1. To get a comparison and strengthen the theory of influencing among the variables studied, it is necessary to do a research or review using different research objects or in the same industry with different locations as in other areas in Jakarta.

2. Future studies can use a wider and wider number of samples, and add more recent research references and reviews so that research results are accurate.

3. In future studies, research variables can be added such as job satisfaction, career development, compensation that can be investigated also whether these variables can affect motivation and work discipline

\section{REFERENCE}

Damayanti, D., \& Fakhri, M. (2014). Pengaruh Budaya Organisasi Terhadap Disiplin Kerja Karyawan Pt Angkasa PuraIi (Persero) Kantor Cabang Utama Bandara Internasional Soekarno-Hatta Unit Personnel \& General Affairs. eProceedings of Management, 1(3).

Edy Sutrisno. 2016. Manajemen Sumber Daya Manusia. Jakarta : Kencana Greenberg, Jerald dan Baron, Robert A. 2010. Perilaku Organisasi. Jakarta : Prentice Hall

Malayu S.P. Hasibuan. 2012. Organisasi dan Motivasi. Jakarta : PT. Bumi Aksara

Kreitner Robert dan Kinicki Angelo, 2014, Perilaku Organisasi, Edisi 9, Buku ke2, Jakarta: Salemba Empat

Kanfer, R., Frese, M., \& Johnson, R. E. (2017). Motivation related to work: A century of progress. Journal of Applied Psychology, 102(3), 338.

Luthans, F., Youssef, C. M., \& Rawski, S. L. (2011). A tale of two paradigms: The impact of psychological capital and reinforcing feedback on problem solving and innovation. Journal of Organizational Behavior Management, 31(4), 333-350.

Pribadi, Muhammad.Herlena, Benny(2016).PERAN BUDAYA ORGANISASI TERHADAP DISIPLIN KERJA KARYAWAN DIREKTORAT PRODUKSI PT KRAKATAU STEEL (PERSERO) TBK CILEGON..PSYMPATHICPsympathic, Jurnal Ilmiah Psikologi Desember 2016, Vol. 3, No. 2, Hal: 225 - 234. DO 10.15575/psy.v3i2.1112 
Puspita,G. Sudarijati(2018). PENGARUH BUDAYA KERJA DAN IKLIM KERJA TERHADAP DISIPLIN KERJA

PEGAWAI KANTOR PERTANAHAN KOTA BOGOR. Jurnal Visionida, Volume 4 Nomor 1 Juni 2018. DOI: http://dx.doi.org/10.30997/jvs.v4i1.1309.

Sutoro, S. (2020). Pengaruh Budaya Organisasi terhadap Motivasi Kerja Pegawai BPSDM Provinsi Jambi. Jurnal Ilmiah Universitas Batanghari Jambi, 20(1), 104-112. DOI: http://dx.doi.org/10.33087/jiubj.v20i1.863. ISSN 1411-8939 (Online) | ISSN 25494236 (Print)

Masykur, R., Septuri, S., \& Setiawati, Y. (2019). Pengaruh Budaya Organisasi terhadap Motivasi Kerja Guru di Sekolah Dasar Ar-Raudah Bandar Lampung. AL-IDARAH: JURNAL KEPENDIDIKAN ISLAM, 9(1), 38-48.

Purba, M. A. (2017). Pengaruh Budaya Organisasi Terhadap Motivasi Kerja Karyawan Pada Pt Bursa Efek Indonesia (Bei) Jakarta Selatan.

Riani, Asri Laksmi. 2011. Budaya Organisasi. Yogyakarta: Graha Ilmu.

Rivai, V., \& Mulyadi, D. (2012). Kepimpinan dan Perilaku Organisasi. Jakarta: PT RajaGrafindo.

Saputra, T. (2019). Pengaruh Motivasi Kerja Terhadap Disiplin Kerja Karyawan Pada Hotel Permai Pekanbaru. Jurnal Benefita: Ekonomi Pembangunan, Manajemen Bisnis \& Akuntansi, 4(2), 316-325. http://doi.org/10.22216/jbe.v4i2.1548. ublished by LLDIKTI Wilayah X,Khatib Sulaiman Street Padang,West Sumatera, Indonesia,Phone: +62751705637.Fax: +62751705637.Email: jurnal.1ldikti10@ristekdikti.go.id.E ISSN 2477-7862

Suwarto, F. X. dan D. Koeshartono., 2010. Budaya Organisasi; Kajian Konsep dan Implementasi. Yogyakarta: Universitas Atma Jaya

Saputra, T. (2016). Pengaruh Motivasi Kerja Terhadap Disiplin Kerja Pegawai Pada Dinas Pemuda Dan Olahraga Provinsi Riau. Jurnal Niara, 8(2), 50-60.

Sanjaya, J. (2020). Pengaruh Kecerdasan Emosional, Motivasi dan Kompensasi Terhadap Disiplin Kerja Karyawan di BMT Pahlawan dan BMT Istiqomah Tulungagung.

Tintami, L., Pradhanawati, A., \& Nugraha, H. S. (2013). Pengaruh Budaya Organisasi dan Gaya Kepemimpinan Transformasional terhadap Kinerja Karyawan Melalui Disiplin Kerja pada Karyawan harian SKT Megawon II PT. Djarum Kudus. Jurnal Ilmu Administrasi Bisnis, 1(1), 189-196

Wibowo. 2010. Manajemen Kinerja. Edisi Ketiga. Raja Grafindo Prasada. Jakarta. 